\title{
Wilder Penfield, Man of Letters
}

\author{
François Mai, Adjunct Professor, Department of Psychiatry, \\ Queen's University, Kingston, Ontario, Canada
}

Can J Neurol Sci. 2012; 39: 845-846

The wide-ranging interests of Wilder Penfield may surprise many who are more familiar with him as one of the leading neurosurgeons of the 20th century. Born in the United States (US) in 1891, he came to Canada in 1928 and founded the Montreal Neurological Institute in 1934. His pioneer research into the surgical treatment of epilepsy remains pertinent even today. He began his medical career as a Rhodes Scholar at Oxford in 1914 and obtained his MD at Johns Hopkins in 1918. His premedical degree was in literature at Princeton where he was a top honour's student and excelled in both football and wrestling. He died in 1976 and was awarded many honours during his life time. In 1994 he was inducted into the Canadian Medical Hall of Fame.

While at Oxford, between 1914 and 1916, he came under the influence of two men, Sir Charles Sherrington and Sir William Osler, who were to have a profound influence on him. Sherrington was a neurophysiologist, but also a poet and a philosopher; Osler, a physician, also an author and a humanitarian. Penfield $^{1,2}$ imbibed the thinking and practices of these two men and made them his own.

Penfield's expert knowledge of archaeology, ancient history and human nature is exemplified in his novels ${ }^{3,4}$. No Other Gods is the story of Abraham's captivity in the city of Ur in Sumeria, his escape and flight to Canaan with his half-sister, Sarah, and a small group of followers. Abraham is portrayed as an idealist and a powerful believer in God and in Truth. During a visit to Iran and Iraq in 1943 Penfield visited the ruins of Ur and was enthralled with the archeology and history of the area, and its ancient civilizations. He returned to the Middle East in 1949 and spent weeks in the museums of Baghdad and the ruins of Ur gathering material for his book ${ }^{5}$. These travels and experiences provided the spur to write and complete the novel.

The Torch is a fictionalized life of Hippocrates. Penfield concedes there are few known facts about Hippocrates' life and much elaborated myth. What is known is that Hippocrates firmly established medicine as a science and an art separate from religion and witchcraft. Penfield weaves both fact and myth into a readable and absorbing biography of the father of medicine. From a psychiatric perspective I was intrigued to find Penfield (speaking through Hippocrates) using imitation or "modeling" as a diagnostic criterion for hysteria. Hippocrates' female patient had observed someone having an epileptic convulsion and she unconsciously used this as a basis for her own symptom. Penfield shows that he was knowledgeable and sensitive to human nature and to psychological mechanisms in health and disease.

The two novels have much in common. Abraham and Hippocrates were both charismatic leaders who left lasting legacies on humankind. Both were great teachers, as was Penfield. One wonders if Penfield's interest in them was because he himself identified with their mission; both Abraham and Hippocrates wished to make the world a better place for their people and their followers and in his autobiography Penfield gives this as one of the driving forces of his own life and work ${ }^{6}$.

Penfield's extensive knowledge and perspective is evident also in his other books. The Second Career ${ }^{7}$ is a compendium of selected addresses and essays concerned with education, history and his philosophy of life. In addition to Sherrington and Osler his heroes included Ramón y Cajal and Alan Gregg. In a chapter entitled "A Doctor's Philosophy" presented to graduating medical students he strongly encouraged them to take an active interest in literature and art. He states, "Universities that do not encourage doctors to explore the Humanities allow them to emerge into the practice of medicine with a cultural handicap" 8 .

From the Medical Expertise Division, Human Resources and Skills Development Canada, Ottawa; Department of Psychiatry, Queen's University, Kingston, Ontario, Canada.

Received June 7, 2012. Final Revisions Submitted June 26, 2012. Correspondence to: François Mai, Medical Expertise Division, Human Resources and Skills Development Canada, 355 North River Road, Tower 5A, Ottawa, Ontario, K1A OL1, Canada. Email: francois.mai@hrsdc-rhdcc.gc.ca. 
He frequently cites the Old and New Testaments and historical figures such as Socrates, Plato, Khalil Gibran and Shakespeare. He urged doctors to have heroes, just as Osler was one of his.

Another chapter is entitled "Learning a Foreign Language". Penfield learnt French whilst working in a Military Hospital in France during World War 1. This experience proved crucial when he moved to Montréal in 1928 where he was able to bring English and French-speaking neurologists and neurosurgeons together in events leading up to setting up the Montreal Neurological Institute (MNI) ${ }^{9}$

The Institute was established with the assistance of a substantial grant from the Rockefeller Foundation, which maintained its support for many years thereafter through an Endowment Fund. Penfield strongly supported the principle of endowment, rather than short-term grants, as a method of promoting quality research. Alan Gregg was the Director of the Division of Medical Sciences of the Rockefeller Foundation from 1931-1951and played a leading part in funding the MNI. After Gregg's death in 1959 and at the request of his wife, Penfield penned a biography of Gregg ${ }^{10}$. In this work he emphasised the crucial role that philanthropy plays in medical research and education, and analysed the psychology and politics behind philanthropy. Giving is "difficult" because it has to be done wisely and in a timely manner. Gregg did not need gratitude for his support. To him, helping to set up a "heritage of excellence" was all he expected. Penfield provides a full-life picture of Gregg and in doing so reveals many of his own attitudes and opinions. For example, Gregg was a strong supporter of psychiatrists and psychiatric research; John Romano, Lawrence Kubie and Stanley Cobb were eminent recipients of Foundation support. Some of Penfield's most noteworthy results came from his collaboration with psychologists such as Brenda Milner.

Penfield did not shrink from expressing humanitarian opinions on political issues of the day. In a presentation on "Mankind in the Atomic Age" given in 1961 at the height of the Cold War" ${ }^{11}$ Penfield proposed "an offensive of understanding, brotherhood and friendship by the people of the West towards the people of the East". He made practical suggestions, such as language learning and travel, to illustrate how these objectives could be accomplished. ${ }^{12}$

Penfield has a fluid writing style and the dialogue between his fictionalized characters in the novels flow seamlessly. All his books are readable, thought-provoking, and witty. For example, we find Hippocrates stating, when he was puzzled by the behaviour of a woman in his entourage, "Women! a fascinating subject for study - but medicine is so much simpler!". The novels are filled with colourful descriptions of the land, waters, boats and wildlife, these being based clearly on visits to the areas he is portraying.

Penfield was a scholar and a humanitarian who had an interest in many disciplines other than medicine. Natural curiosity broadened his influence in Society and provided leverage for his surgical and administrative accomplishments. His non-medical writings are fascinating and highlight his career as a role model for physicians. He ended an address on the Use of Idleness with inspirational words ${ }^{13}$ :

"Beware of the great social disease, the closure of the windows of the mind, the loneliness of selfish solitude, the isolation that limits achievement of so many specialists. Welcome the wind from the Ocean of Truth. Walk on its shores and be content to pick up the pebbles you find, listening there for the whisper of wisdom meant for every man."

\section{REFERENCES}

1. Penfield W. No man alone. Boston: Little, Brown and Co; 1977. p. 34-8.

2. Ibid. The second career. Boston: Little, Brown and Co; 1963. p. 57-75.

3. Ibid. No other gods. Boston: Little, Brown and Co; 1954.

4. Ibid. The torch. Boston: Little, Brown and Co; 1960.

5. Ibid. The second career. Boston: Little, Brown and Co; 1963. p. 37-56.

6. Ibid. No man alone. Boston: Little, Brown and Co; 1977. p. 18-19.

7. Ibid. The second career. Boston: Little, Brown and Co; 1963.

8. Ibid. The second career. Boston: Little, Brown and Co; 1963. p. 171.

9. Ibid. No man alone. Boston: Little, Brown and Co; 1977. p. 192-8.

10. Ibid. The difficult art of giving. Boston: Little, Brown and Co; 1967.

11. Ibid. The second career. Boston: Little, Brown and Co; 1963. p. $177-81$.

12. Ibid. The second career. Boston: Little, Brown and Co; 1963. p. $180-1$.

13. Ibid. The second career. Boston: Little, Brown and Co; 1963. p. $188-9$. 